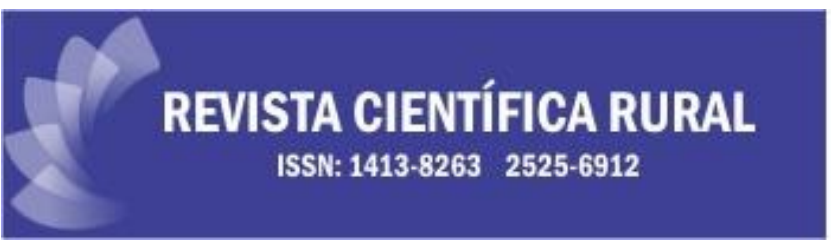

\title{
STRESS CONDITIONS AND ITS EFFECTS ON THE PHYSIOLOGICAL POTENTIAL OF PAPAVER SP. SEEDS
}

\author{
Andréa Bicca Noguez Martins¹, Ivan Ricardo Carvalho², Giordano Gelain Conte ${ }^{1}$, Anna dos \\ Santos Suñe ${ }^{1}$, Bruna Barreto Dos Reis ${ }^{1}$, Lilian Madruga de Tunes ${ }^{1}$ \\ ${ }^{1}$ Universidade Federal de Pelotas - Doutorado em Ciência e Tecnologia de Sementes; ${ }^{2}$ Universidade Regional do \\ Noroeste do Estado do Rio Grande do Sul - Pós-Doutorado em Plantas de Lavoura e Ciência e Tecnologia de \\ Sementes
}

\begin{abstract}
The physiological quality of seeds is commonly characterized by the germination and vigor, which can be defined as the sum of attributes that confers the potential for seeds to germinate, rapidly emerge and result in normal seedlings under a wide range of environmental conditions. The purpose of thestudy was to test alternative methodologies for the accelerated aging test to evaluate the physiological potential of poppy seeds.Samples obtained from four batches were subjected to germination test at a temperature of $20{ }^{\circ} \mathrm{C}$, traditional accelerated aging and accelerated aging diluted with saline solution $(11 \mathrm{~g}$ of $\mathrm{NaCl}$ in $100 \mathrm{~mL}^{-1}$ of water) using three temperatures, $41^{\circ} \mathrm{C}, 42^{\circ} \mathrm{C}$ and $43^{\circ} \mathrm{C}$, for periods of 12 and 24 hours. The percentage of germination, the rate of emergence velocity, performed together with the emergence speed and the percentage of seedling emergence test were evaluated.It is concluded that the methodology of traditional accelerated aging with temperature of $43{ }^{\circ} \mathrm{C}$ and period of $12 \mathrm{~h}$ shows to be promising for the verification of the physiological quality of poppy seeds.
\end{abstract}

Keywords: physiological assessment, accelerated aging with saline, poppy seeds.

\section{CONDIÇÕES DE ESTRESSE E SEUS EFEITOS NO POTENCIAL FISIOLÓGICO DE PAPAVER SP. SEMENTES}

RESUMO: A qualidade fisiológica das sementes é comumente caracterizada pela germinação e vigor, que pode ser definida como a soma de atributos que confere o potencial de germinação das sementes, emergem rapidamente e resultam em plântulas normais sob uma ampla gama de condições ambientais. $O$ objetivo do estudo foi testar metodologias alternativas para o teste de envelhecimento acelerado para avaliar o potencial fisiológico de sementes de papoula. Amostras obtidas de quatro lotes foram submetidas ao teste de germinação a $20^{\circ} \mathrm{C}$, envelhecimento acelerado tradicional e envelhecimento acelerado diluído em soro fisiológico (11 g de NaCl em $100 \mathrm{~mL}-1$ de água) em três temperaturas, $41^{\circ} \mathrm{C}, 42^{\circ} \mathrm{C}$ e $43^{\circ} \mathrm{C}$, por períodos de 12 e 24 horas. $\mathrm{A}$ porcentagem de germinação, a velocidade de emergência, realizada juntamente com a velocidade de emergência e o percentual de teste de emergência de 
plântulas foram avaliadas. Conclui-se que a metodologia do envelhecimento acelerado tradicional com temperatura de $43^{\circ} \mathrm{C}$ e período de $12 \mathrm{~h}$ mostra-se promissora para a verificação da qualidade fisiológica das sementes de papoula.

Palavras-chave: avaliação fisiológica, envelhecimento acelerado com sal, sementes de papoula.

\section{INTRODUCTION}

The poppy (Papaver spp.) is grown as an annual crop in countries such as China, India, Czechoslovakia or Turkey. It is mainly used for extraction of opium and as oleaginous (ÖZCAN; ATALAY, 2006).

In seeds, the physiological quality has been characterized by germination and vigor.Vigor can be defined as the sum of attributes that conferst the seed the potential to germinate, emerge and rapidly result in normal seedlings under a wide range of environmental conditions. In vigor tests the main objective is to identify differences in the physiological potential of seed lots, especially those with high and similar germinative potential (MARCOS FILHO, 1999b).There is little information on the evaluation of the physiological potential of poppy seeds, so there is a need to test methods capable of identifying differences in the physiological potential of seed lots.

Different methods have been proposed to evaluate the physiological potential of the seeds (MARCOS FILHO, 1999), in order to obtain a reliable estimate of the performance of the seed lots in the field and/or storage, and the accelerated aging test is one of the most used (MELLO; TILLMANN , 1987; VIEIRA; CARVALHO, 1994; FERGUSON-SPEARS, 1995).

The accelerated aging test consists in subjecting the seeds to adverse conditions of high temperature $\left(40-45^{\circ} \mathrm{C}\right)$ and relative air humidity of $100 \%$, during a certain period, and then to observe the response through the standard germination test (MARCOS FILHO, 1999). The test has shown reliable results, since it evaluates the behavior of the seeds when subjected to stress conditions, thus seeking to estimate the relative storage potential of the lots, presenting results related to the field emergence of seedlings (DELOUCHE; BASKIN, 1973). This test is based on assumption that the rate of seed deterioration is considerably increased by its exposure to high temperature and relative humidity, 
being the environmental factors that are most related to the deterioration of the seeds. Thus, seed lots with high vigor will remain viable after being stressed, while those with low vigor will have their viability reduced (AOSA, 1983).

For some species, such as soybean, corn and wheat, accelerated aging studies are already standardized, that is, indicate the temperature and the ideal period to perform this test, in order to classify the seeds for their vigor. However, for ornamental species the use of the test is still limited.

Studies performed with species that generate seeds with small size has revealed results with low consistency, due to the much-accentuated variation of the humidity degree of the sample after aging (RAMOS et al., 2004). The alternatives for conducting the accelerated aging test with seeds of these species have been studied, such as the substitution of water for salts solutions. Depending on the solution used, specific levels of relative air humidity are obtained, allowing to reduce water absorption rate, speed and seed deterioration intensity (JIANHUA; MCDONALD, 1996), without reducing the sensitivity of the test.

The objective of this study was to test alternative methods of the accelerated aging test to evaluate the physiological potential of poppy seeds.

\section{MATERIAL AND METHODS}

The study was carried out at the Laboratory of Seed Analysis - LDAS of the Federal University of Pelotas - UFPel. Samples of poppy seeds from four lots were analyzed, being performed tests of germination, accelerated aging, emergence speed index, emergence speed and total emergence.

The germination test was carried out with subsamples of 50 seeds for each batch, distributed equally on kraft paper placed in gerbox boxes, kept under controlled temperatures of $20^{\circ} \mathrm{C}$, until the tenth day, the number of normal seedlings was counted obtaining the percentage of germination (G) (Brasil, 2009).

The accelerated aging test was conducted in two ways.According to methodology recommended by AOSA (1983) and complemented by Marcos Filho (1999) with alterations.For the traditional accelerated aging test (TAA) a 
single layer of 0.09 to 0.11 grams of seeds were distributed in a uniform layer on a metal screen coupled to a gerbox containing $40 \mathrm{~mL}$ of distilled water in the bottom and kept in an incubator (BOD) at $41{ }^{\circ} \mathrm{C}, 42{ }^{\circ} \mathrm{C}$ and $43{ }^{\circ} \mathrm{C}$ for 12 to 24 hours.After each period, six subsamples of 50 seeds were placed to germinate, following the method described for the germination test.A single evaluation was performed on the tenth day after sowing, computing the percentage of normal seedlings.In the accelerated aging test with dilute saline solution (AADSS), it was carried out in the same way as in the TAA, replacing distilled water with $\mathrm{NaCl}$ solution (11 g NaCl in $100 \mathrm{~mL}$ of water) (Costa et al., 2008). The results were expressed as percentage of germination.

The emergence speed index (ESI) was performed together with the emergency speed (ES) and the seedling emergence percentage test (E).In commercial substrate for $\mathrm{H}$. Dequer $®$ vegetables the seeds were distributed equidistantly at $0.5 \mathrm{~cm}$ depth in gerboxes filled with a $1.5 \mathrm{~cm}$ layer of substrate.The substrate was moistened with distilled water and the boxes kept under $20^{\circ} \mathrm{C}$. The verification of the number of normal emerged seedlings and the need for irrigation were observed daily until the stabilization of the emergence.The design was completely randomized, with four replicates of 50 seeds per lot.

For each repetition, the ESI was calculated by adding the number of plants emerged each day divided by the number of days elapsed from the sowing, according to Maguire (1962), by the formula:

$$
E S I=\frac{E 1}{N 1}+\frac{E 2}{N 2}+\cdots+\frac{E n}{N n}
$$

Being: $E S I=$ emergence speed index;E1, E2, En = number of emerged seedlings, computed in the first, second and last count;N1, N2, Nn = number of days of sowing to the first, second and last count.

For the calculation of the ES, adding the number of plants emerged each day, divided by the number of days elapsed from the sowing, according to Edmond and Drapala (1958), by the formula:

$$
E S=\frac{[(N 1 E 1)+(N 2 E 2)+\cdots(N n E n)]}{E 1+E 2+\cdots+E n}
$$


Being: ESemergence speed;E1, E2, En = number of emerged seedlings, computed in the first, second and last count;N1, N2, Nn = number of days of sowing to the first, second and last count.

The value of $E$ was obtained by the total number of emerged seeds in each repetition.

Using the SAS software (2013), the data obtained in each test were submitted to variance analysis and the means were compared by the Tukey test, at $5 \%$.Then, a correlation analysis between all variables was analyzed using the Pearson correlation ( $r)$.

\section{RESULTS}

In the evaluation of the initial quality of the lots, referring to $G$ and $E$ (table 1), no significant differences were observed, although there was a reduction in the number of normal seedlings when comparing $G$ and $E$. Similar results were obtained by Barbosa et al. (2012) for eggplant, cauliflower and tomato. These seeds showed developmental delay in germination, possibly related to environmental conditions in which they were produced.

Tabela 1. Valores médios obtidos para germinação (G), emergência (E), velocidade de emergência (ES), índice de velocidade de emergência (ESI), resultados expressos em porcentagem. Capão do Leão. UFPel, Pelotas-RS, 2018.

Table 1. Mean values obtained for germination (G), emergence (E), emergence speed (ES), emergence speed index (ESI), results expressed in percentage. Capão do Leão. UFPel, Pelotas-RS, 2018.

\begin{tabular}{ccccc}
\hline Lots & G & E & ES & ESI \\
\hline Lot 1 & $69 \mathrm{a}$ & $35 \mathrm{a}$ & $5,53 \mathrm{c}$ & $6,43 \mathrm{a}$ \\
Lot 2 & $73 \mathrm{a}$ & $30 \mathrm{a}$ & $6,39 \mathrm{~b}$ & $3,92 \mathrm{ab}$ \\
Lot 3 & $72 \mathrm{a}$ & $24 \mathrm{a}$ & $7,28 \mathrm{a}$ & $2,35 \mathrm{ab}$ \\
Lot 4 & $65 \mathrm{a}$ & $18 \mathrm{a}$ & $6,96 \mathrm{ab}$ & $3,58 \mathrm{~b}$ \\
\hline
\end{tabular}

Numbers followed by the same letter do not differ in column by Tukey test at $5 \%$ of significance.

The ESI and ES (table 1) values allowed observing significant differences between the lots, classifying them in different levels of physiological quality. In the evaluation of ESI, it is observed that lot 1 was classified as superior, followed by lot 2 , which did not differ significantly from lot 3 , and lot 4 was of lower quality.Of the 12 accelerated aging methodologies tested, nine showed a significant ESI correlation. 
In ES (table 1) it is observed that lot 3 was classified as superior followed by lot 4 and 3 , lot 1 presented inferior quality when compared to the others.

It is verified that, in seed lots with low vigor, there is a greater drop in their viability after exposure to the aging stress treatment (MARCOS FILHO, 2005), therefore, there is a possibility of establishing differences in the physiological potential of these lots (PANOBIANCO; MARCOS FILHO, 2001).

In the accelerated aging test, in the studied periods (table 2 ) of TAA $41^{\circ} \mathrm{C}$ 24h, TAA and AADSS $41^{\circ} \mathrm{C} 12 \mathrm{~h}$, TAA $42^{\circ} \mathrm{C} 24 \mathrm{~h}$, TAA and AADSS $42{ }^{\circ} \mathrm{C} 24 \mathrm{~h}$ and $12 \mathrm{~h}$, TAA and AADSS $43^{\circ} \mathrm{C} 24 \mathrm{~h}$, TAA $43^{\circ} \mathrm{C}$ and $12 \mathrm{~h}$, it is verified greater vigor for lot 1 , followed by lots 2 and 3 , with worse overall for batch 4 .

Lots 2 and 3 (table 2) were classified as medium vigor, in exception of lot 2 in three cases,AADSS $12 \mathrm{~h}$ at $41^{\circ} \mathrm{C}$, AADSS $24 \mathrm{~h}$ at $42^{\circ} \mathrm{C}$ and AADSS $12 \mathrm{~h}$ at $43{ }^{\circ} \mathrm{C}$, where it did not differ statistically from the first batch.According to Marcos Filho (1999), the identification of the physiological potential of the medium-vigor batches is often more difficult, since these batches may present variations in their behavior, sometimes equaling the vigorous lots, or those with less vigor, depending on the employed force test.

Therefore, the different periods of seed exposure to the accelerated aging test at $42^{\circ} \mathrm{C}$ and $43^{\circ} \mathrm{C}$ presented results similar to the ESI, ES and E tests, allowing to classify the lots into similar vigor levels. 
Tabela 2. Valores médios para envelhecimento acelerado tradicional (TAA) e envelhecimento acelerado com solução salina diluída (AADSS) de sementes de papoila em relação à temperatura e período de exposição. Resultados expressos em porcentagem. Capão do Leão. UFPel, Pelotas-RS, 2018.

Table 2. Mean values for traditional accelerated aging (TAA) and accelerated aging with diluted saline solute (AADSS) of poppy seeds in relation to temperature and period of exposition.

Resultsexpressed in percentage. Capão do Leão. UFPel, Pelotas-RS, 2018.

\begin{tabular}{|c|c|c|c|c|}
\hline \multirow{3}{*}{$\begin{array}{l}\text { Lots } \\
\text { Lot } 1\end{array}$} & \multicolumn{2}{|c|}{$41^{\circ} \mathrm{C} 24 \mathrm{~h}$} & \multicolumn{2}{|c|}{$41^{\circ} \mathrm{C} 12 \mathrm{~h}$} \\
\hline & \multirow{2}{*}{$\begin{array}{l}\text { TAA } \\
57 \mathrm{a}\end{array}$} & \multirow{2}{*}{$\frac{\text { AADSS }}{0 \mathrm{~b}}$} & TAA & \multirow{2}{*}{$\frac{\text { AADSS }}{81 \mathrm{a}}$} \\
\hline & & & 73 a & \\
\hline Lot 2 & $55 a$ & 48 a & $61 a b$ & $72 a b$ \\
\hline Lot 3 & $33 \mathrm{~b}$ & $14 \mathrm{~b}$ & $56 \mathrm{~b}$ & $58 \mathrm{~b}$ \\
\hline Lot 4 & $0 \mathrm{c}$ & $3 b$ & $54 \mathrm{~b}$ & $72 \mathrm{~b}$ \\
\hline \multirow{2}{*}{ Lots } & \multicolumn{2}{|c|}{$42^{\circ} \mathrm{C} 24 \mathrm{~h}$} & \multicolumn{2}{|c|}{$42^{\circ} \mathrm{C} 12 \mathrm{~h}$} \\
\hline & TAA & AADSS & TAA & AADSS \\
\hline Lot 1 & $41 a$ & $23 \mathrm{c}$ & $68 a$ & $70 a$ \\
\hline Lot 2 & $21 \mathrm{~b}$ & $78 a$ & $42 \mathrm{~b}$ & $35 \mathrm{~b}$ \\
\hline Lot 3 & $18 \mathrm{~b}$ & $45 \mathrm{~b}$ & $26 \mathrm{c}$ & $21 \mathrm{~b}$ \\
\hline Lot 4 & $4 \mathrm{c}$ & $31 \mathrm{c}$ & $22 \mathrm{c}$ & $22 b$ \\
\hline \multirow{2}{*}{ Lots } & \multicolumn{2}{|c|}{$43^{\circ} \mathrm{C} 24 \mathrm{~h}$} & \multicolumn{2}{|c|}{$43^{\circ} \mathrm{C} 12 \mathrm{~h}$} \\
\hline & TAA & AADSS & TAA & AADSS \\
\hline Lot 1 & $45 a$ & 66 a & $67 \mathrm{a}$ & $17 \mathrm{bc}$ \\
\hline Lot 2 & $32 \mathrm{~b}$ & $30 \mathrm{~b}$ & $35 \mathrm{~b}$ & $27 \mathrm{ab}$ \\
\hline Lot 3 & $4 \mathrm{c}$ & $18 \mathrm{bc}$ & $18 \mathrm{~b}$ & $14 \mathrm{c}$ \\
\hline Lot 4 & $5 \mathrm{c}$ & $8 c$ & $23 \mathrm{~b}$ & 32 a \\
\hline
\end{tabular}

Numbers followed by the same letter do not differ in column by Tukey test at $5 \%$ of significance.

To verify the consistency of the information obtained by the analysis of the means comparison, a correlation analysis was performed, and the data presented showed differences in the magnitude and direction of the correlation values.

No accelerated aging methodology showed significant correlation with $\mathrm{G}$ (table 3). The correlation data obtained between ESI, ES and E (table 3) accelerated aging test methodologies make it clear that different vigor tests can be used in poppy seeds.

Eight positive and significant correlations (table 3) were obtained between the aging and ESI methodologies, and between this and TAA $43^{\circ} \mathrm{C} 12 \mathrm{~h}$ was the correlation of higher magnitude $(0.757)$ followed by AADSS $43^{\circ} \mathrm{C} 12 \mathrm{~h}(0.714)$.

For ES (table 3 ), the smaller its value is, the lesser vigor it possess. Comparing this variable, there was obtained nine significant correlations (table 3): AADSS $12 \mathrm{~h} 42{ }^{\circ} \mathrm{C}(-0.877)$, TAA $43^{\circ} \mathrm{C} 24 \mathrm{~h}(-0.838)$ TAA $43^{\circ} \mathrm{C} 12 \mathrm{~h}(-0.818)$, 
TAA $42{ }^{\circ} \mathrm{C} 24 \mathrm{~h}(-0.778)$, AADSS $42{ }^{\circ} \mathrm{C} 12 \mathrm{~h}(-0.798)$ and AADSS $43{ }^{\circ} \mathrm{C} 24 \mathrm{~h}(-$ $0.735)$.

Tabela 3. Coeficientes de correlação para germinação (G), emergência (E), velocidade de emergência

$(E S)$, índice de velocidade de emergência ( $E S I)$, envelhecimento acelerado tradicional (TAA), envelhecimento acelerado com soluto salino diluído (AADSS) de sementes de papoila. Capão do Leão. UFPel, Pelotas-RS, 2018.

Table 3. Correlation coefficients for germination (G), emergence (E), emergence speed (ES), emergence speed index (ESI), traditional accelerated aging (TAA), accelerated aging with diluted saline solute (AADSS) of poppy seeds. Capão do Leão. UFPel, Pelotas-RS, 2018.

\begin{tabular}{|c|c|c|c|c|c|c|c|c|c|c|c|c|c|c|c|c|}
\hline \multirow[b]{2}{*}{ Variables } & \multirow[b]{2}{*}{ G } & \multirow[b]{2}{*}{ E } & \multirow[b]{2}{*}{ ES } & \multirow[b]{2}{*}{ ESI } & \multicolumn{2}{|c|}{$41^{\circ} \mathrm{C} 24 \mathrm{~h}$} & \multicolumn{2}{|c|}{$41^{\circ} \mathrm{C} 12 \mathrm{~h}$} & \multicolumn{2}{|c|}{$42^{\circ} \mathrm{C} 24 \mathrm{~h}$} & \multicolumn{2}{|c|}{$42^{\circ} \mathrm{C} 12 \mathrm{~h}$} & \multicolumn{2}{|c|}{$43^{\circ} \mathrm{C} 24 \mathrm{~h}$} & \multicolumn{2}{|c|}{$43^{\circ} \mathrm{C} 12 \mathrm{~h}$} \\
\hline & & & & & TAA & $\begin{array}{c}\text { AADS } \\
\mathrm{S}\end{array}$ & TAA & $\begin{array}{c}\text { AADS } \\
S\end{array}$ & TAA & $\begin{array}{c}\text { AADS } \\
S\end{array}$ & TAA & $\begin{array}{l}\text { AADS } \\
S\end{array}$ & TAA & $\begin{array}{c}\text { AADS } \\
S\end{array}$ & TAA & $\begin{array}{c}\text { AADS } \\
S\end{array}$ \\
\hline G & 1 & $0, \overline{155}$ & 0,132 & $-0,255$ & 0,306 & 0,335 & 0,267 & 0,119 & 0,004 & 0,168 & $-0,027$ & $-0,078$ & 0,135 & 0,187 & 0,055 & $-0,361$ \\
\hline$E$ & & 1 & $0, \overline{784}$ & $\underset{*}{0,927}$ & 0,441 & $-0,145$ & 0,447 & $0,587^{*}$ & $\underset{*}{0,520}$ & $-0,016$ & $\underset{\star}{0,582}$ & $0,613^{*}$ & $\underset{*}{0,540}$ & 0,425 & $\underset{*}{0,637}$ & $-0,075$ \\
\hline ES & & & 1 & $\underset{*}{0,869}$ & $\underset{*}{-\overline{6}} \underset{*}{-}$ & 0,139 & $\underset{\star}{0,659}$ & $0, \overline{-} 0^{*}$ & $\underset{*}{0} \underset{*}{-}$ & 0,155 & $\underset{*}{0} \underset{*}{-}$ & $\stackrel{-}{0,798^{*}}$ & $\underset{*}{-} \underset{*}{-}$ & $\stackrel{-}{0,735^{*}}$ & $\underset{\star}{0,818}$ & 0,062 \\
\hline ESI & & & & 1 & 0,425 & $-0,344$ & $\underset{*}{0,528}$ & $0,570^{*}$ & $\underset{*}{0,639}$ & $-0,270$ & $\underset{*}{0,670}$ & $0,714^{*}$ & $\underset{*}{0,630}$ & $0,567^{*}$ & $\underset{*}{0,757}$ & $-0,174$ \\
\hline $41^{\circ} \mathrm{C} 24 \mathrm{~h}$ TAA & & & & & 1 & 0,354 & $\underset{*}{0,436}$ & $0,576^{*}$ & $\underset{*}{0,800}$ & 0,315 & $\underset{*}{0,724}$ & $0,622^{*}$ & $\underset{*}{0,795}$ & $0,735^{\star}$ & $\underset{*}{0,549}$ & $-0,339$ \\
\hline $\begin{array}{l}41^{\circ} \mathrm{C} 24 \mathrm{~h} \\
\text { AADSS }\end{array}$ & & & & & & 1 & $-0,100$ & 0,063 & $-0,118$ & $0,878^{*}$ & $-0,206$ & $-0,193$ & 0,117 & $-0,122$ & $-0,214$ & 0,082 \\
\hline $41^{\circ} \mathrm{C} 12 \mathrm{~h}$ TAA & & & & & & & 1 & $0,406^{*}$ & $\underset{*}{0,479}$ & $-0,203$ & $\underset{*}{0,582}$ & $0,598^{*}$ & $\underset{*}{0,631}$ & $0,675^{\star}$ & $\underset{*}{0,721}$ & $-0,148$ \\
\hline $\begin{array}{l}41^{\circ} \mathrm{C} 12 \mathrm{~h} \\
\text { AADSS }\end{array}$ & & & & & & & & 1 & $\underset{*}{0,577}$ & $-0,041$ & $\underset{*}{0,590}$ & $0,608^{*}$ & 0,679 & $0,627^{*}$ & 0,530 & $-0,201$ \\
\hline $42^{\circ} \mathrm{C} 24 \mathrm{~h}$ TAA & & & & & & & & & 1 & $-0,169$ & $\underset{\star}{0,865}$ & $0,779^{*}$ & $\underset{*}{0,795}$ & $0,849^{*}$ & $\underset{*}{0,755}$ & $-0,391$ \\
\hline $\begin{array}{l}42^{\circ} \mathrm{C} 24 \mathrm{~h} \\
\text { AADSS }\end{array}$ & & & & & & & & & & 1 & $-0,201$ & $-0,359$ & 0,042 & $-0,235$ & $-0,250$ & 0,126 \\
\hline $42^{\circ} \mathrm{C} 12 \mathrm{~h}$ TAA & & & & & & & & & & & 1 & $0,826^{*}$ & $\underset{*}{0,837}$ & $0,878^{*}$ & $\underset{*}{0,762}$ & $-0,067$ \\
\hline $\begin{array}{l}42^{\circ} \mathrm{C} 12 \mathrm{~h} \\
\text { AADSS }\end{array}$ & & & & & & & & & & & & 1 & $\underset{*}{0,790}$ & $0,846^{*}$ & $\underset{*}{0,708}$ & $-0,119$ \\
\hline $43^{\circ} \mathrm{C} 24 \mathrm{~h}$ TAA & & & & & & & & & & & & & 1 & $0,876^{*}$ & $\underset{*}{0,798}$ & $-0,124$ \\
\hline $\begin{array}{l}43^{\circ} \mathrm{C} 24 \mathrm{~h} \\
\text { AADSS }\end{array}$ & & & & & & & & & & & & & & 1 & $\underset{*}{0,862}$ & $-0,177$ \\
\hline $43^{\circ} \mathrm{C} 12 \mathrm{~h}$ TAA & & & & & & & & & & & & & & & 1 & $-0,045$ \\
\hline $\begin{array}{l}43^{\circ} \mathrm{C} 12 \mathrm{~h} \\
\text { AADSS }\end{array}$ & & & & & & & & & & & & & & & & 1 \\
\hline
\end{tabular}

\section{DISCUSSION}

According to Tomes et al.(1988) smaller seeds shows greater sensitivity to the accelerated aging test (table 2).Due to the small size of poppy seeds, when performing the test it was used shorter periods than those generally used, between 48 and 96 hours to horticultural crops and ornamental species (Squeegee et al 2000; Ramos et al 2004; Bhering et al 2006; Costa et al 2008; Menezes et al 2008; Barbosa et al 2011; Demir et al, 2011; Tunes et al 2011a; Tunes et al 2011b; Alves et al 2012; Kikuti and Marcos Filho 2012). 
Considering $\mathrm{E}$ (table 3), there were seven significant correlations, with the highest magnitude between the variable and TAA $43^{\circ} \mathrm{C} 12 \mathrm{~h}(0.637)$. The fact that there were reduced and non-significant correlation coefficients between the different vigor tests and the accelerated aging methodology, in the present study, do not imply discarding the methodologyfor future studies in poppy. In addition, it is important to carry out new research, if possible including a larger number of lots, to obtain definitive inferences regarding the inclusion of accelerated aging methods in laboratory activities.

According to studies by Schuab et al. (2006) and Tunes et al. (2011a), the correlation analysis is efficient in verifying the associations between the initial seed quality tests of and the accelerated aging methodologies tested, helping in the selection of the best accelerated aging methods, capable of detecting vigor differences between lots of seeds. poppy seeds.

\section{CONCLUSIONS}

The traditional accelerated aging methodology with a temperature of $43^{\circ} \mathrm{C}$ and a $12 \mathrm{~h}$ period is promising for the physiological quality of poppy seeds as it correlates in a large magnitude with the speed emergence index, speed emergence and total emergence, promoting better stratification of poppy seeds lots.

\section{REFERENCE}

ALVES, C.Z.; SÁ, M.E. Adequação da metodologia do teste de envelhecimento acelerado em sementes de rúcula. Semina: Ciências Agrárias, Londrina, v.33, suplemento 1, p.2789-2798, 2012. DOI: 10.5433/1679-0359.2012v33Supl1p2789

BARBOSA, R. M.; COSTA, D. S.; SÁ, M. E. Envelhecimento acelerado de sementes de espécies oleráceas. Pesquisa Agropecuária Tropical, Goiânia, v. 41, n. 3, p. 328-335, 2011. e-ISSN 1983-4063. Disponível em: <ftp:// www.agro.ufg.br/pat. Acesso em: 10 jun 2018.

BHERING, M.C.; DIAS, D.C.F.S.; VIDIGAL, D.S.; NAVEIRA, D.S.P. Teste de envelhecimento acelerado em sementes de pimenta. Revista Brasileira de Sementes, Pelotas, v.28, n.3, p.64-71, 2006.

BRASIL. Ministério da Agricultura, Pecuária e Abastecimento. Regras para análise de sementes. Ministério da Agricultura, Pecuária e Abastecimento. Secretaria de Defesa Agropecuária. Brasília, DF: Mapa/ACS, 395p. 2009. 
Disponível em: <ftp://www.agricultura.gov.br_analise_sementes>. Acesso em: 15 jun 2018.

COSTA, C.J.; TRZECIAK, M.B.; VILLELA, F.A. Potencial fisiológico de sementes de brássicas com ênfase no teste de envelhecimento acelerado. HorticulturaBrasileirav.26, p.144-148. 2008.

DELOUCHE, J.C.; BASKIN, C.C. Accelerated aging techniques for predicting the relative storability of seed lots. Seed Science and Technology v.1, p. 427-452. 1973.

EDMOND, J. B.; DRAPALA, W. J. The effects of temperature, sand and soil, and acetone on germination of okra seed. Proceedings of the American Society Horticutural Science, Alexandria, n. 71, p. 428-434, 1958.

JIANHUA, Z.; McDONALD, M.B. The saturated salt accelerated aging test for small-seeded crops. Seed Science and Technology, Zürich, v.25, n.1, p.123-131, 1997.

KIKUTI, A.L.P.; MARCOS FILHO, J. Potencial fisiológico de sementes de couveflor e desempenho das plantas em campo. RevistaBrasileira de Sementes, Pelotas, v.29, n.1, p.107-113, 2007.

MAGUIRE, J.D. Speed of germination-aid selection and evaluation for seedling emergence and vigor. Crop Science, v.2, n. 2, p.176-177, 1962.

MARCOS FILHO, J. Teste de envelhecimento acelerado. In: KRZYZANOWSKI, F. C.; VIEIRA, R.D.; FRANÇA NETO, J.B. (Ed.). Vigor de sementes: conceitos e testes. Londrina: ABRATES, p.3.1-3.24. 1999.

MELLO VDC; TILLMANN MAA. O teste de vigor em câmara de envelhecimento precoce. Revista Brasileira de Sementes, Brasília, v.9, n.2, p. 93-102. 1987.

MENEZES, V.O.; PEDROSO, D.C. MUNIZ, M.F.B.; BELLÉ, R.; BLUME, E.; GARCIA, D.C. Envelhecimento aceleradoem sementes de ZinniaelegansJacq.colhidas em diferentes épocas. RevistaBrasileira de Sementes, Brasília, v. 30, n.3, p.039-047, 2008.

ÖZCAN, M. Musa; Atalay, ÇĭgdemDeterminationofseedandoilpropertiesof some poppy (Papaversomniferum L.) varietiesGrasas y aceites, 57 (2), ABRIL-JUNIO, 169-174, 2006.

PANOBIANCO, M.; MARCOS FILHO, J. Envelhecimento acelerado e deterioração controlada em sementes de tomate. ScientiaAgricola, n.58, p.525531. 2001.

RAMOS, N.P.; FLOR, E.P.O.; MENDONÇA, E. A.F.; MINAMI, K. Envelhecimento acelerado em sementes de rúcula (Eruca sativa L.). Revista Brasileira de Sementes, Pelotas, v.26, n.1, p.98-103, 2004.

RODO, A.B.; PANOBIANCO, M.; MARCOS FILHO, J. Metodologia alternativa do teste de envelhecimento acelerado para sementes de cenoura. ScientiaAgricola, Piracicaba, v.57, n.2, p.289-292, 2000. 
SAS Institute, The SAS system for Windows, Release 9,2, SAS Inst, Cary, NC. 2013.

SCHUAB, S. R. P.; BRACCINI, A. L.; FRANÇA NETO, J. B.; SCAPIM, C. A.; MESCHEDE, D. K. Potencial fisiológico de sementes de soja e sua relação com a emergência das plântulas em campo. Acta Scientiarum. Agronomy, v. 28, n. 4, p. 553-561, 2006.

TUNES, L.M., TAVARES, L.C., RUFINO, C.A., VIEIRA, J.F., ACUNHA, T.S., BARROS, A.C.S.A. AND MUNIZ, M.F.B. AcceleratedAgingofOnionSeeds (Allium cepa L.) SubmittedtoSaturated Salt Solution. Revista Colombiana de Ciências Hortícolas, 5, 244-250. 2011 a.

TUNES, L.M.; PEDROSO, D.C.; BARBIERI, A.P.P.; CONCEIÇÃO, G.M.; ROETHING, E.; MUNIZ, M.F.B.; BARROS, A.C.S.A. Envelhecimento acelerado modificado para sementes de coentro (Coriandrumsativum L.) e sua correlação com outros testes de vigor. Revista Brasileira de Biociências 9: 12-17. $2011 \mathrm{~b}$.

TOMES, L.J.; TEKRONY, D.M.; EGLI, D.B. Factors influencing the tray accelerated aging test for soybean seed. Journal of Seed Technology, East Lansing, v.12, n.1, p.24-35, 1988.

VIEIRA, R.D.; CARVALHO, N.M. Testes de vigor em sementes. Jaboticabal: FUNEP. 164p. 1994. Disponível em: <ftp://www.bdpa.cnptia.embrapa.br. Acesso em: 13 jul 2018. 